\title{
Rancang Bangun Sistem Pemesanan Jadwal Laundry Self Service Berbasis Website Menggunakan Protokol MQTT
}

\author{
Salma Febrila ${ }^{1)}$, Nugroho Suharto ${ }^{2}$, Lis Diana Mustafa ${ }^{3)}$ \\ ${ }^{1}$ Program Studi Jaringan Telekomunikasi Digital \\ 2,3 Program Studi Teknik Telekomunikasi \\ Jurusan Teknik Elektro, Politeknik Negeri Malang, Indonesia \\ 1salmafebrila@gmail.com, ${ }^{2 n u g r o h o . s u h a r t o @ p o l i n e m a . a c . i d, ~}{ }^{3}$ lisdianamustafa16@gmail.com
}

\begin{abstract}
In this study, customers had to queue in order to get their turn for laundry. So that users need a long time so it is less time efficient. This self-service laundry has a washing schedule booking service through the website making it easier for laundry service users without the need to queue. The method used in this study is an application for ordering laundry schedules via the website and an RFID tag as a card to access self-service laundry services. First, the user registers with customer service to get an RFID tag in the form of a smart card containing the user's identity and balance so that they can operate the washing machine. This research measures the accuracy of the weight sensor, the accuracy of the RFID distance, and the communication system between hardware and software. In the test results, the accuracy of the weight sensor obtained an error percentage of $0.28 \%$ to $1.69 \%$. In testing the accuracy of the RFID distance, the reading of the RFID tag with a reader was obtained from a distance of $0 \mathrm{~cm}$ to $3 \mathrm{~cm}$. In testing QoS (Quality of Service) using parameters delay, packet loss and throughput. In the delay test, the test results obtained are $0.057 \mathrm{~ms}$ to $15.426 \mathrm{~ms}$. In the packet loss test it was obtained 0\%. Whereas in the throughput test, the results obtained are around 0.337 Kbps to 6,758 Kbps.
\end{abstract}

Keywords - laundry self service, schedule, website, RFID

Abstrak - Pada penelitian ini pelanggan harus mengantri terlebih dahulu agar mendapat giliran me-laundry. Sehingga pengguna membutuhkan waktu yang lama sehingga kurang efisien waktu. Laundry self service sendiri mengharuskan pengguna jasa melakukan kegiatan mencuci sendiri sehingga tidak terjadi kehilangan pakaian. Laundry self service ini memiliki layanan pemesanan jadwal mencuci melalui website sehingga memudahkan pengguna jasa laundry tanpa perlu antri. Metode yang digunakan pada penelitian ini berupa aplikasi pemesanan jadwal me-laundry melalui website dan tag RFID sebagai kartu untuk mengakses jasa laundry self service. Pertama pengguna mendaftarkan diri terlebih dahulu ke customer service untuk mendapatkan tag RFID berupa smart card yang berisi identitas pengguna dan saldo agar dapat mengoperasikan mesin cuci tersebut. Pada penelitian ini mengukur akurasi sensor berat, akurasi jarak RFID, dan sistem komunikasi antara hardware dan software. Pada hasil pengujian nilai akurasi sensor berat diperoleh presentase error sebesar $0.28 \%$ sampai $1.69 \%$. Pada pengujian akurasi jarak RFID diperoleh hasil pengukuran terbacanya tag RFID dengan reader dari jarak $0 \mathrm{~cm}$ sampai $3 \mathrm{~cm}$. Pada pengujian QoS (Quality of Service) menggunakan parameter delay, packet loss dan throughput. Pada pengujian delay diperoleh hasil pengujian sebesar $0.057 \mathrm{~ms}$ sampai $\mathbf{1 5 . 4 2 6} \mathrm{ms}$. Pada pengujian packet loss diperoleh 0\%. Sedangkan pada pengujian throughput diperoleh hasil sekitar 0.337 Kbps sampai 6.758 Kbps.

Kata kunci-laundry self service, jadwal, website, RFID.

\section{PENDAHULUAN}

Di era modern saat ini banyak orang yang menginginkan kemudahan dalam berbagai hal. Namun kemudahan ini kurang didukung dari pelayanan jasanya. Seperti pada jasa laundry, banyak pengguna yang mengeluhkan kehilangan pakaian mereka. Menurut BPSK (Balai Pelayanan Sengketa Konsumen) Kota Malang merangkum 20 pengaduan sepanjang 2018. Mulai dari aduan konsumen finance, jasa servis, jasa laundry, jasa pengiriman barang dan konsumen maskapai penerbangan. Pada jasa laundry kebanyakan konsumen mengadukan kehilangan pakaian. Tetapi pihak laundry hanya memberi janji akan mencarikan tanpa ada kepastian dan tidak mau mengganti. Menurut UU Nomor 8 Tahun 1999 tentang Perlindungan Konsumen, pemilik usaha menjamin mutu barang dan/atau jasa yang diproduksi dan/atau diperdagangkan berdasarkan ketentuan standar mutu barang dan/atau jasa yang berlaku, pemilik usaha memberi kompensasi, ganti rugi dan/atau penggantian atas kerugian akibat penggunaan, pemakaian dan pemanfaatan barang dan/atau jasa yang diperdagangkan dan pemilik usaha memberi kompensasi, ganti rugi dan/atau penggantian apabila barang dan/atau jasa yang diterima atau dimanfaatkan tidak sesuai dengan perjanjian. Seharusnya pemilik usaha laundry menjamin bahwa jasa laundry yang dimiliki sesuai dengan apa yang diperjanjikan dengan menjaga agar pakaian yang di-laundry kembali ke tangan konsumen secara utuh.

Pada penelitian sebelumnya yaitu Ricky Gunawan, dkk (2017) yang meneliti tentang "Liquid Laundry (Perencanaan Pendirian Usaha Jasa Laundry Koin)" [1], melakukan perencanaan pendirian usaha laundry self sevice menggunakan 
metode pembayaran koin. Pada penelitian ini pelanggan harus mengantri terlebih dahulu agar mendapat giliran me-laundry. Sehingga pengguna membutuhkan waktu yang lama sehingga kurang efisien waktu.

Dengan adanya penelitian tersebut penelitian ini diusulkan untuk sistem "Rancang Bangun Pemesanan Smart Laundry Berbasis Arduino Menggunakan Protokol MQTT". Hasil penelitian ini diharapkan dapat membantu pengguna jasa laundry tidak perlu mengantri karena sebelumnya telah memesan jadwal mencuci melalui website yang telah disediakan, mengurangi tingkat kehilangan pakaian dengan semua kegiatan mencuci dilakukan sendiri dan sistem pembayaran dimudahkan dengan smart card.

\section{METODE}

Penelitian yang dilakukan termasuk dalam jenis penelitian dan pengembangan yang bertujuan untuk merancang sebuah sistem untuk memesan jadwal me-laundry dengan menggunakan metode pembayaran tag RFID.

\section{A. Rancangan Penelitan}

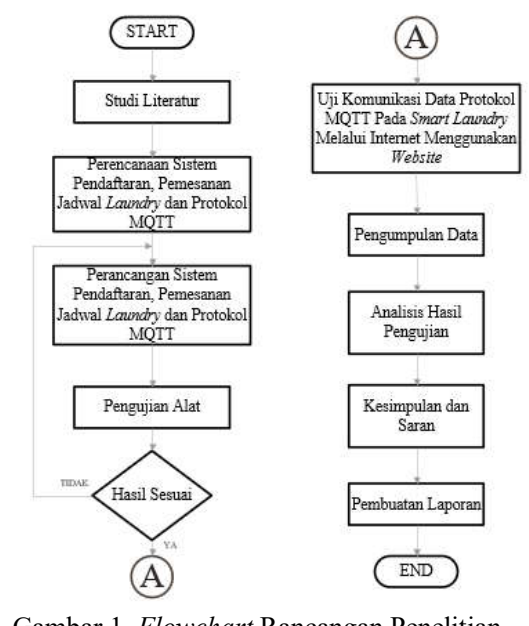

B. Blok Diagram

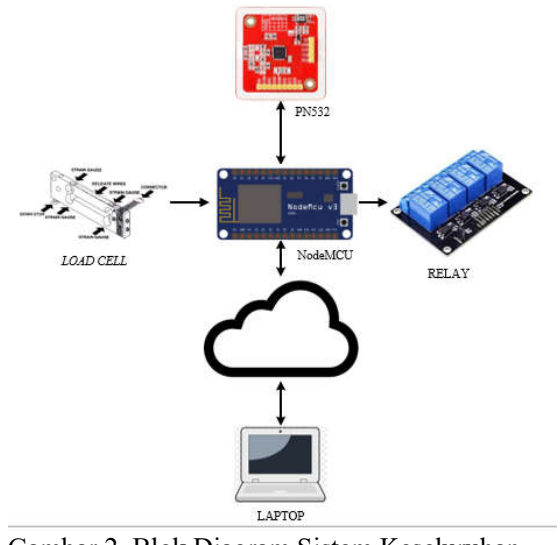

Gambar 2. Blok Diagram Sistem Keseluruhan

Gambar 2. menjelaskan bahwa perangkat penelitian terdiri dari PN532, loadcell, NodeMcu, Relay, dan Laptop. Setiap bagian memiliki perannya masing-masing. Setiap bagian tersebut memiliki perannya masing-masing. Keterangan untuk tiap bagian adalah sebagaimana berikut:

\section{1) PN532}

PN532 berperan sebagai pembaca informasi dari RFID card agar dapat melakukan proses pembayaran dan melanjutkan informasi agar relay dapat bekerja.

\section{2) Load cell}

Load cell berperan sebagai pengukur berat pakaian yang akan dicuci, dimana berat ini digunakan untuk mengetahui jasa yang harus dibayarkan.

\section{3) $\mathrm{NodeMCU}$}

NodeMcu berperan sebagai pengolah data dan modul wireless agar dapat mentransmisikan data pada sistem.

4) Relay

Relay berperan sebagai kontrol mesin cuci.

5) Laptop

Laptop berperan untuk melakukan pemesanan jadwal melaundry dan remote untuk pengoperasian mesin cuci.

C. Flowchart Keseluruhan Sistem

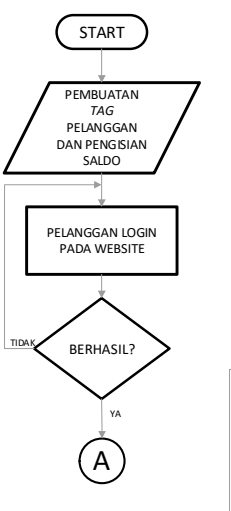

A)
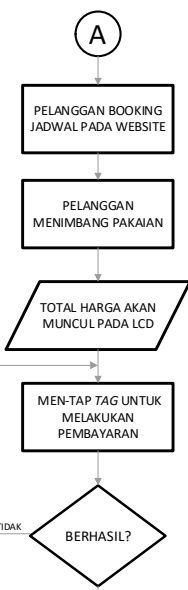

(B)
Gambar 3. Flowchart Keseluruhan Sistem

\section{Flowchart Website Admin}
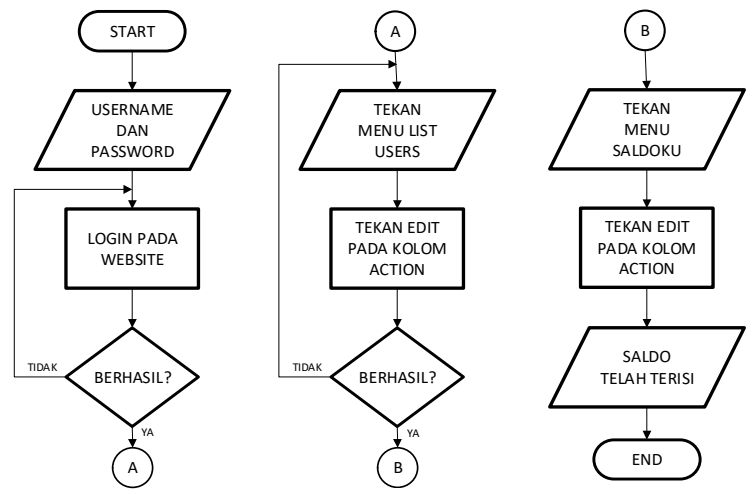

Gambar 4. Flowchart Website Admin
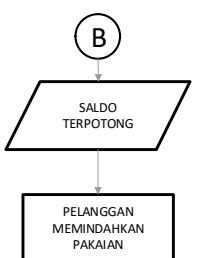

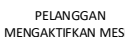
CUCI MELLLUU TOMBOL
PADA WEBSTE

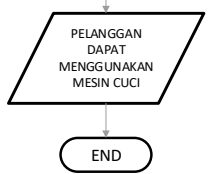

END 


\section{E. Flowchart Website User}

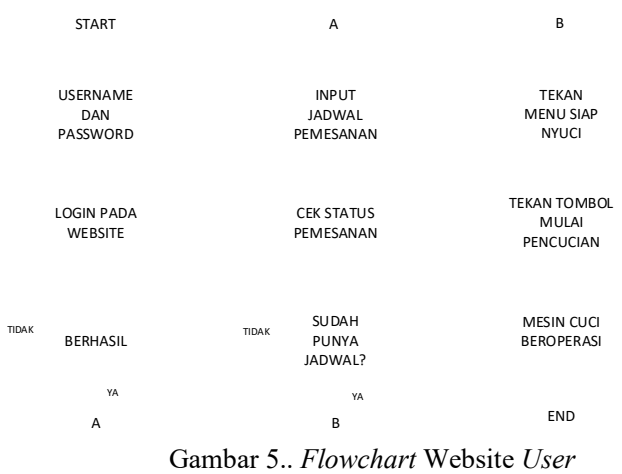

\section{F. Flowchart Pengisian Saldo}

$$
\begin{gathered}
\text { START } \\
\text { A= Saldo awal user } \\
\text { B= Jumlah isi saldo } \\
\text { C= Saldo akhir user } \\
\text { Proses Pengecekan } \\
\text { (A) } \\
\\
\text { Input (B) } \\
\text { Apakah (B)>= } \\
10 \text { ribu? } \\
\text { YIDAK } \\
\text { Proses Pengisian } \\
\text { (C) }=(\text { A })+(\text { B }) \\
\end{gathered}
$$

END

Gambar 6. Flowchart Pengisian Saldo

\section{HASIL DAN PEMBAHASAN}

\section{A. Hasil Implementasi Hardware}

Hasil implementasi hardware akan menjelaskan mengenai tampilan hardware yang akan digunakan sebagai penimbangan dan pembayaran menggunakan load cell dan RFID read and write. Dalam sistem ini terdapat 1 keranjang timbang dan 2 kotak hardware untuk pendaftaran dan pembayaran.

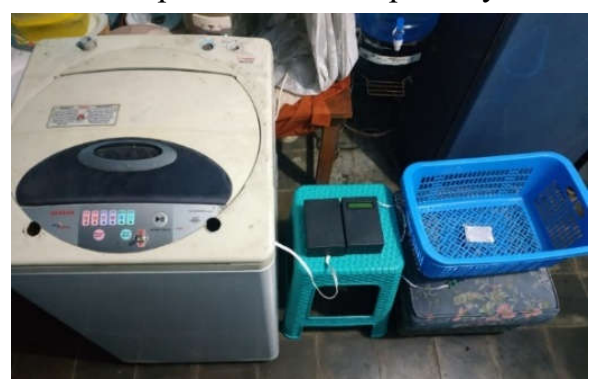

Gambar 7. Tampilan Keseluruhan Hardware

\section{B. Hasil Implementaasi Software}

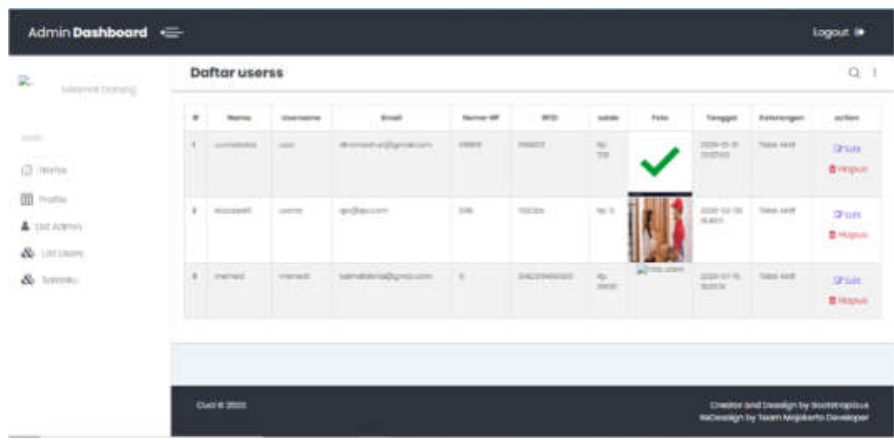

Gambar 8. Tampilan Website Admin

Gambar 8. menunjukkan tampilan website admin yang berisi daftar user yang telah terdaftar ataupun baru mendaftar. Daftar user inilah yang akan di edit sesuai biodata user.

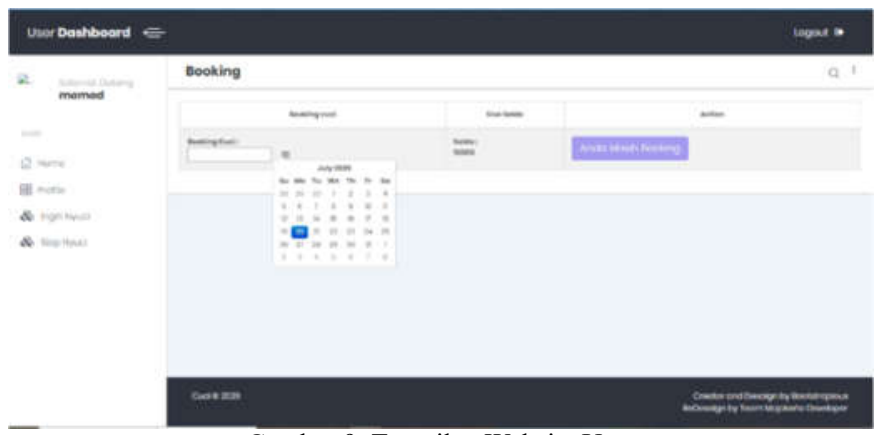

Gambar 9. Tampilan Website User

Gambar 9. menunjukkan gambar tampilan website user dimana pengguna memiliki username dan password untuk mengakses website. Pada website ini pengguna dapat membooking jadwal me-laundry mulai dari tanggal sampai jam sesuai yang diinginkan.

\section{Pengujian Akurasi Sensor Berat}

Pengujian dilakukan untuk mengetahui akurasi berat yang dibaca oleh load cell dibandingkan dengan timbangan digital dapat bekerja dengan baik atau tidak.

\section{Hasil Sensor Berat}

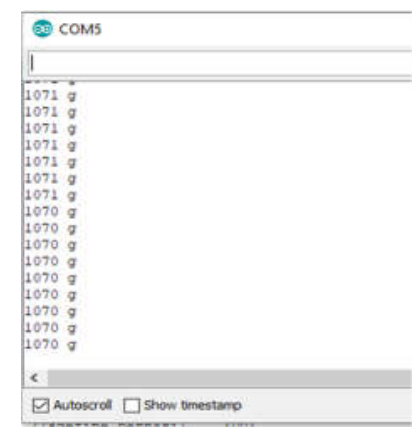

Gambar 10. Hasil Pengujian Akurasi Sensor Berat
Hasil Timbangan

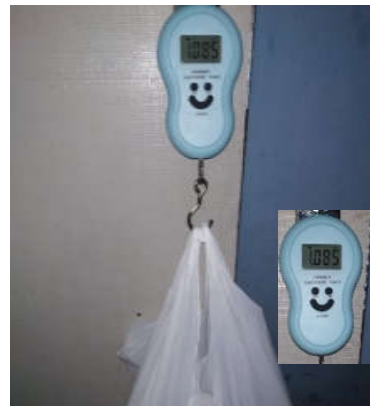


Jurnal Jaringan Telekomunikasi E-ISSN: 2654-6531 P-ISSN: 2407-0807 Vol. 10, No.4 (2020) 207-212

TABEL I.

HASIL PENGUJIAN LOAD CELL

\begin{tabular}{|c|c|c|c|c|c|}
\hline \multirow{2}{*}{$\begin{array}{c}\text { Berat Objek } \\
\text { (Terbaca } \\
\text { pada } \\
\text { Timbangan } \\
\text { Digital) } \\
\text { (gram) }\end{array}$} & \multicolumn{3}{|c|}{ Berat Sensor } & \multirow{2}{*}{$\begin{array}{c}\text { Berat } \\
\text { Rata- } \\
\text { rata } \\
\text { (gram) }\end{array}$} & \multirow{2}{*}{$\begin{array}{c}\text { Persentase } \\
\text { Error }\end{array}$} \\
\hline & $\begin{array}{c}\text { Uji } 1 \\
\text { (gram) }\end{array}$ & $\begin{array}{c}\text { Uji } 2 \\
\text { (gram) }\end{array}$ & $\begin{array}{c}\text { Uji } 3 \\
\text { (gram) }\end{array}$ & & \\
\hline 1085 & 1071 & 1071 & 1070 & 1070.67 & $1.32 \%$ \\
\hline 2055 & 2021 & 2020 & 2020 & 2020.33 & $1.69 \%$ \\
\hline 3090 & 3082 & 3082 & 3082 & 3081.33 & $0.28 \%$ \\
\hline 4035 & 4020 & 4020 & 4021 & 4020.33 & $0.36 \%$ \\
\hline
\end{tabular}

Pada Tabel 1. merupakan hasil pembacaan sensor berat pada timbangan digital dengan load cell. Hasil dari load cell diambil 3 kali pengujian dengan jumlah baju yang sama pada masingmasing titik berat. Dengan presentase error terbesar pada 2055 gram yaitu $1.69 \%$.

\section{Pengujian Akurasi RFID Read and Write}

Pengujian akurasi RFID dilakukan untuk mengetahui jarak optimal RFID read and write pada penelitian ini dapat bekerja dengan baik atau tidak.

TABEL II.

Hasil Pengujian SENSOR UltrasoniK

\begin{tabular}{llllll}
\hline No & Jarak & Uji 1 & Uji 2 & Uji 3 & $\begin{array}{c}\text { Persentase } \\
\text { Keberhasilan }\end{array}$ \\
\hline 1 & $5 \mathrm{~cm}$ & Gagal & Gagal & Gagal & $0 \%$ \\
2 & $4 \mathrm{~cm}$ & Gagal & Gagal & Gagal & $0 \%$ \\
3 & $3 \mathrm{~cm}$ & Sukses & Sukses & Sukses & $100 \%$ \\
4 & $2 \mathrm{~cm}$ & Sukses & Sukses & Sukses & $100 \%$ \\
5 & $1 \mathrm{~cm}$ & Sukses & Sukses & Sukses & $100 \%$ \\
6 & $0 \mathrm{~cm}$ & Sukses & Sukses & Sukses & $100 \%$ \\
\hline
\end{tabular}

Pada tabel 2. merupakan hasil pembacaan RFID reader dengan tag RFID. Jarak yang diambil dari $5 \mathrm{~cm}$ sampai $0 \mathrm{~cm}$. Indikator terbacanya tag RFID adalah munculnya no tag RFID pada lcd. Sedangkan indicator tidak terbacanya tag RFID adalah munculnya kalimat “Tap Kartu RFID” pada lcd. Presentase keberhasilan $100 \%$ muncul pada jarak $0 \mathrm{~cm}$ sampai $3 \mathrm{~cm}$.

\section{E. Pengujian Quality of Service (QoS)}

Pengujian QoS bertujuan untuk mengetahui performansi sistem dengan mengukur beberapa parameter yaitu delay, throughput, dan packet loss. Pengambilan data selama 7 hari dengan 3 kali pengambikan data dalam sehari.

$$
\text { TABEL III. }
$$

STANDARISASI DELAY MENURUT TIPHON (TELECOMMUNICATIONS AND INTERN PROTOCOL HAMONIZATION OVER NEWORKS)

\begin{tabular}{cc}
\hline Kategori Delay & Besar Delay \\
\hline Sangat Bagus & $<150 \mathrm{~ms}$ \\
Bagus & $150 \mathrm{~s} / \mathrm{d} 400 \mathrm{~ms}$ \\
Sedang & $300 \mathrm{~s} / \mathrm{d} 450 \mathrm{~ms}$ \\
Jelek & $.450 \mathrm{~ms}$ \\
\hline
\end{tabular}

TABEL IV.

STANDARISASI PACKET LOSS MENURUT TIPHON

\begin{tabular}{cc}
\hline Kategori Packet Loss & Besar Packet Loss \\
\hline Sangat Bagus & $0 \%$ \\
Bagus & $3 \%$ \\
Sedang & $15 \%$ \\
Jelek & $.25 \%$ \\
\hline & \\
STANDARISASI THROUGHPUT MENURUT TIPHON \\
\hline Kategori Throughput & Besar Throughput \\
\hline Jelek & $0-338 \mathrm{Kbps}$ \\
Cukup & $338-700 \mathrm{Kbps}$ \\
Baik & $700-1200 \mathrm{Kbps}$ \\
Sangat Baik & $>1200 \mathrm{Kbps}$ \\
&
\end{tabular}

1) Pengujian delay menggunakan rumus:

$\operatorname{Delay}(s)=$ waktu diterima - waktu dikirim

$\operatorname{Delay}(s)=11.939969000-11.939907000$

$=0.00062 \mathrm{~s}$

TABEL VI.

Pengujian Delay

\begin{tabular}{|c|c|c|c|}
\hline HARI & WAKTU & $\begin{array}{l}\text { DELAY } \\
\quad(\mathrm{ms})\end{array}$ & $\begin{array}{c}\text { Standarisasi pada } \\
\text { TIPHON }\end{array}$ \\
\hline \multirow{4}{*}{$\begin{array}{c}\text { KAMIS } \\
30-7- \\
2020\end{array}$} & PAGI (11:00) & 0.62 & Sangat Bagus \\
\hline & $\begin{array}{l}\text { SIANG } \\
(15: 00)\end{array}$ & 10.954 & Sangat Bagus \\
\hline & $\begin{array}{c}\text { SORE } \\
(19: 00)\end{array}$ & 8.109 & Sangat Bagus \\
\hline & PAGI (11:00) & 7.253 & Sangat Bagus \\
\hline \multirow[t]{3}{*}{$\begin{array}{c}\text { JUMAT } \\
31-7- \\
2020\end{array}$} & $\begin{array}{l}\text { SIANG } \\
(15: 00)\end{array}$ & 7.11 & Sangat Bagus \\
\hline & $\begin{array}{l}\text { SORE } \\
(19: 00)\end{array}$ & 2.279 & Sangat Bagus \\
\hline & PAGI (11:00) & 2.071 & Sangat Bagus \\
\hline \multirow[t]{3}{*}{$\begin{array}{l}\text { SABTU } \\
1-8-2020\end{array}$} & $\begin{array}{l}\text { SIANG } \\
(15: 00)\end{array}$ & 1.785 & Sangat Bagus \\
\hline & $\begin{array}{l}\text { SORE } \\
(19: 00)\end{array}$ & 3.693 & Sangat Bagus \\
\hline & PAGI (11:00) & 0.508 & Sangat Bagus \\
\hline \multirow{3}{*}{$\begin{array}{c}\text { MINGG } \\
\text { U } \\
2-8-2020\end{array}$} & $\begin{array}{l}\text { SIANG } \\
(15: 00)\end{array}$ & 9.572 & Sangat Bagus \\
\hline & $\begin{array}{l}\text { SORE } \\
(19: 00)\end{array}$ & 7.713 & Sangat Bagus \\
\hline & PAGI (11:00) & 3.603 & Sangat Bagus \\
\hline \multirow[t]{2}{*}{$\begin{array}{l}\text { SENIN } \\
3-8-2020\end{array}$} & $\begin{array}{l}\text { SIANG } \\
(15: 00)\end{array}$ & 8.505 & Sangat Bagus \\
\hline & $\begin{array}{l}\text { SORE } \\
(19: 00)\end{array}$ & 15.426 & Sangat Bagus \\
\hline SELASA & PAGI (11:00) & 0.057 & Sangat Bagus \\
\hline $4-8-2020$ & $\begin{array}{l}\text { SIANG } \\
(15: 00)\end{array}$ & 0.059 & Sangat Bagus \\
\hline
\end{tabular}


Jurnal Jaringan Telekomunikasi E-ISSN: 2654-6531 P-ISSN: 2407-0807 Vol. 10, No.4 (2020) 207-212

\begin{tabular}{cccc}
\hline HARI & WAKTU & $\begin{array}{c}\text { DELAY } \\
(\mathbf{m s})\end{array}$ & $\begin{array}{c}\text { Standarisasi pada } \\
\text { TIPHON }\end{array}$ \\
\hline & $\begin{array}{c}\text { SORE } \\
(19: 00)\end{array}$ & 0.072 & Sangat Bagus \\
& PAGI (11:00) & 4.501 & Sangat Bagus \\
RABU & $\begin{array}{l}\text { SIANG } \\
(15: 00)\end{array}$ & 0.145 & Sangat Bagus \\
$5-8-2020$ & $\begin{array}{c}\text { SORE } \\
(19: 00)\end{array}$ & 0.070 & Sangat Bagus \\
& & & \\
\hline
\end{tabular}

Pada tabel 6 merupakan pengujian delay selama tujuh hari. Dari hasil selama tujuh hari didapat hasil $<150 \mathrm{~ms}$ sehingga hasil yang didapat mendapat standarisasi sangat bagus pada TIPHON (Telecommunication and Internet Protocol Harmonization Over Network).

2) Pengujian packet loss menggunakan rumus:

Packet Loss $=$ Dropped Packet

Packet Loss $=0 \%$

TABEL VII

PenguJIAN PACKET LosS

\begin{tabular}{|c|c|c|c|}
\hline HARI & WAKTU & $\begin{array}{l}\text { PACKET } \\
\text { LOSS }(\%)\end{array}$ & $\begin{array}{l}\text { Standarisasi } \\
\text { pada TIPHON }\end{array}$ \\
\hline \multirow{4}{*}{$\begin{array}{l}\text { KAMIS } \\
30-7-2020\end{array}$} & PAGI (11:00) & $0 \%$ & Sangat Bagus \\
\hline & & & \\
\hline & SIANG (15:00) & $0 \%$ & Sangat Bagus \\
\hline & SORE (19:00) & $0 \%$ & Sangat Bagus \\
\hline \multirow{4}{*}{$\begin{array}{l}\text { JUMAT } \\
31-7-2020\end{array}$} & PAGI (11:00) & $0 \%$ & Sangat Bagus \\
\hline & & & \\
\hline & SIANG (15:00) & $0 \%$ & Sangat Bagus \\
\hline & SORE (19:00) & $0 \%$ & Sangat Bagus \\
\hline \multirow{3}{*}{$\begin{array}{l}\text { SABTU } \\
1-8-2020\end{array}$} & PAGI (11:00) & $0 \%$ & Sangat Bagus \\
\hline & SIANG (15:00) & $0 \%$ & Sangat Bagus \\
\hline & SORE (19:00) & $0 \%$ & Sangat Bagus \\
\hline \multirow{4}{*}{$\begin{array}{l}\text { MINGGU } \\
2-8-2020\end{array}$} & PAGI (11:00) & $0 \%$ & Sangat Bagus \\
\hline & & & \\
\hline & SIANG (15:00) & $0 \%$ & Sangat Bagus \\
\hline & SORE (19:00) & $0 \%$ & Sangat Bagus \\
\hline \multirow{4}{*}{$\begin{array}{l}\text { SENIN } \\
3-8-2020\end{array}$} & PAGI (11:00) & $0 \%$ & Sangat Bagus \\
\hline & CIANC (15.00) & & Sanorat Raous \\
\hline & SIANG (15:00) & $0 \%$ & Sangat Bagus \\
\hline & SORE (19:00) & $0 \%$ & Sangat Bagus \\
\hline \multirow{4}{*}{$\begin{array}{l}\text { SELASA } \\
4-8-2020\end{array}$} & PAGI (11:00) & $0 \%$ & Sangat Bagus \\
\hline & & & \\
\hline & SIANG $(15: 00)$ & $0 \%$ & Sangat Bagus \\
\hline & SORE (19:00) & $0 \%$ & Sangat Bagus \\
\hline
\end{tabular}

\begin{tabular}{llll}
\hline HARI & WAKTU & $\begin{array}{l}\text { PACKET } \\
\text { LOSS (\%) }\end{array}$ & $\begin{array}{l}\text { Standarisasi } \\
\text { pada TIPHON }\end{array}$ \\
\hline $\begin{array}{l}\text { RABU } \\
5-8-2020\end{array}$ & PAGI (11:00) & $0 \%$ & Sangat Bagus \\
& SIANG (15:00) & $0 \%$ & Sangat Bagus \\
& SORE (19:00) & $0 \%$ & Sangat Bagus \\
\hline
\end{tabular}

Pada tabel 8 terlihat bahwa pengujian packet loss selama tujuh hari. Pengiriman data terkirim dengan baik berupa dropped packets $0 \%$. Dari hasil selama tujuh hari didapat hasil packet loss $0 \%$ sehingga hasil yang didapat mendapat standarisasi sangat bagus pada TIPHON. Yang artinya data dikirim ke penerima dengan sangat bagus.

3) PENGUJIAN throughput menggunakan rumus:

Throughput $=\frac{\text { Total Bytes }}{\text { Time Span }(s)}$

Throughput $=\frac{354}{0.419(s)}=844.87 B / s$

Dari hasil perhitungan didapat nilai throughput sebesar $844.87 \mathrm{~B} / \mathrm{s}$. Pada standarisasi THIPON menggunakan satuan Kbps, sehingga $844.87 \mathrm{~B} / \mathrm{s}$ x 8 bit $=6758$ bps $=6.758 \mathrm{Kbps}$.

TABEL IX.

Pengujian Packet Loss

\begin{tabular}{|c|c|c|c|}
\hline HARI & WAKTU & $\begin{array}{l}\text { THROUGHPU } \\
\text { T (Kbps) }\end{array}$ & $\begin{array}{l}\text { Standarisasi } \\
\text { pada TIPHON }\end{array}$ \\
\hline \multirow{3}{*}{$\begin{array}{l}\text { KAMIS } \\
30-7- \\
2020\end{array}$} & PAGI (11:00) & 6.758 & Jelek \\
\hline & SIANG $(15: 00)$ & 0.687 & Jelek \\
\hline & SORE (19:00) & 2.677 & Jelek \\
\hline \multirow{3}{*}{$\begin{array}{l}\text { JUMAT } \\
31-7- \\
2020\end{array}$} & PAGI (11:00) & 1.884 & Jelek \\
\hline & SIANG (15:00) & 1.730 & Jelek \\
\hline & SORE (19:00) & 1.121 & Jelek \\
\hline \multirow{3}{*}{$\begin{array}{l}\text { SABTU } \\
1-8-2020\end{array}$} & PAGI (11:00) & 1.873 & Jelek \\
\hline & SIANG $(15: 00)$ & 1.039 & Jelek \\
\hline & SORE (19:00) & 4.379 & Jelek \\
\hline \multirow{3}{*}{$\begin{array}{l}\text { MINGG } \\
\text { U } \\
2-8-2020\end{array}$} & PAGI (11:00) & 2.248 & Jelek \\
\hline & SIANG $(15: 00)$ & 0.957 & Jelek \\
\hline & SORE (19:00) & 0.337 & Jelek \\
\hline \multirow{3}{*}{$\begin{array}{l}\text { SENIN } \\
3-8-2020\end{array}$} & PAGI (11:00) & 1.071 & Jelek \\
\hline & SIANG $(15: 00)$ & 0.848 & Jelek \\
\hline & SORE (19:00) & 0.691 & Jelek \\
\hline SELASA & PAGI (11:00) & 2.623 & Jelek \\
\hline $4-8-2020$ & SIANG $(15: 00)$ & 1.441 & Jelek \\
\hline
\end{tabular}




\begin{tabular}{llll}
\hline HARI & WAKTU & $\begin{array}{l}\text { THROUGHPU } \\
\text { T (Kbps) }\end{array}$ & $\begin{array}{l}\text { Standarisasi } \\
\text { pada TIPHON }\end{array}$ \\
\hline & SORE (19:00) & 1.655 & Jelek \\
& PAGI (11:00) & 1.164 & Jelek \\
RABU & SIANG (15:00) & 0.894 & Jelek \\
$5-8-2020$ & SORE (19:00) & 1.285 & Jelek \\
& & & \\
\hline
\end{tabular}

Pada tabel IX. merupakan pengujian throughput selama tujuh hari. Kecepatam pengiriman data pada wireshark menggunakan satuan $\mathrm{B} / \mathrm{s}$. sedangkan pada standarisasi THIPON menggunakan satuan Kbps sehingga harus melakukan penyamaan satuan. Dari perhitungan yang telah dihasilkan selama tujuh hari didapat hasil throughput terbesar pada hari kamis pagi yaitu $6.758 \mathrm{Kbps}$. Sehingga hasil yang didapat mendapat hasil jelek pada standarisasi TIPHON.

\section{KESIMPULAN}

Pada pengujian load cell menggunakan 4 titik berat dengan 3 kali pengambilan data didapatkan nilai selisih satu gram pada setiap titik berat yang artinya pembacaan load cell memiliki tingkat kesesuaian mencapai 90\%.

Sistem website pemesanan jadwal laundry dibuat sesuai dengan yang direncanakan yaitu pengguna dapat melakukan pemesanan jadwal pada website dan pada hari pemesanan pengguna dapat mengoperasikan mesin laundry sesuai prosedur yang telah disediakan dengan keakuratan fungsi website pemesanannya sebesar $90 \%$.

Pengujian komunikasi QoS pemesanan jadwal me-laundry dengan menggunakan protocol mqtt, didapatkan hasil pengujian data selama tujuh hari dengan delay sebesar $0.057 \mathrm{~ms}$ sampai $15.426 \mathrm{~ms}$ (sangat baik), sedangkan pengukuran packet loss sebesar $0 \%$ (sangat baik), sedangkan pengukuran throughput sebesar 0.337 Kbps sampai 6.758 Kbps (jelek).

\section{REFERENSI}

[1] G. Ricky , "Liquid Laundry (Perencanaan Pendirian Usaha Jasa Laundry Koin,” 2017 